\title{
An Appraisal of Administrative Justice and Good Governance in
} Nigeria

\author{
Juwayriya Badamasiuy ${ }^{1} \&$ Muhammad Bello $^{1}$ \\ ${ }^{1}$ Private \& Commercial Law Department, Faculty of Law, Bayero University, Kano, Nigeria \\ Correspondence: Juwayriya Badamasiuy, Private \& Commercial Law Department, Faculty of Law, Bayero \\ University, PMB 3011, Kano, Nigeria. Tel: 234-803-704-2552. E-mail: juwabadamasi@yahoo.co.uk
}

Received: March 28, 2013 Accepted: April 22, 2013 Online Published: May 30, 2013

doi:10.5539/jpl.v6n2p216 URL: http://dx.doi.org/10.5539/jpl.v6n2p216

\begin{abstract}
Administrative justice is generally seen as a component of good governance. While the former has developed in Nigeria largely through the Common Law, the latter is a relatively emerging ideal that has eluded public administration in Nigeria. For decades, corruption and maladministration have become the central problems facing the country. The people have suffered and are still suffering from the consequences of poor governance. This article examines administrative justice as an element of good governance in Nigeria. It demonstrates that the problems are the results of misuse of administrative discretion at all levels of government and the lack of sufficient accountability mechanisms. Although efforts have been made to address these problems through legal and intitutional reforms, however, the problems still persist. Using these twin concepts of administrative justice and good governance, this article argues that the legal and institutional reforms undertaken to address the problems have not been effective because they failed to approach the problems from the 'inside-out'. The article partly attributes the failure of the reforms to the restrictive approach in administrative justice, a 'top-bottom' approach bequethed by the common law and incorporated into the general legal and constitutional arrangement in the country. While advocating for a 'bottom-up' approach which constrains the exercise of administrative discretion at all levels, from the individual 'street level bureaucrat' to the top government official, the article proposes the institutionalisation of democratic values of checks and balance, oppenness, transperancy and accountability in decision-taking such that official discretion may be reasonably constrained without jeopardising administrative efficiency.
\end{abstract}

Keywords: administrative justice, good governance, constitution, rule of law, transparency, discretion

\section{Introduction}

Since the attainment of independence in 1960, Nigeria has been grappling with governnace problems; its system of public administration has been characterized by corruption, abuse of power and misgovernance. (Oyewo, 2008). The country has been rated as one of the most corrupt countries in the world having poor accountability mechanisms (Amnesty International (AI), 2007). Institutions in both the public and private sectors have been affected by poor policy choices and decision-makers at all levels have become somewhat 'unrestrained' in the discharge of their functions. The ideals of democratic accountability, justice and good governance are continuously being disregarded. (CLEEN, 2010). This has led to what may be termed as 'a crisis of public administration' in Nigeria. The legal and intitutional checks placed on the exercise of official discretion are provided under the constitution and other laws but the effectiveness of these mechanisms in addressing political maladministration and corruption in the country has been very insignificant. Administrative justice is one of such mechanisms which is largely ignored in the efforts of sanitising the system. The question is, to what extent can administrative justice be employed in the promotion of good governance in the country? This question is critical in the light of the institutional and legislative reforms introduced by the previous and present administrations in order to ensure transperancy and accountability in government.

Administrative justice is a component of justice. And justice is an essential, indispensable core value in any organised, civilised human society. One of the fundamental functions of the state is the administration of justice and in functional terms this could be exercised even outside the traditional adjudicatory system managed by the courts. Although the courts are indispensable state institutions, the administration of justice is no longer within their exclusive province. Institutions, statutory bodies, public authorities and agencies have emerged with enormous administrative powers. They are increasingly assuming and exercising critical adjudicatory functions, 
dispensing justice in a different, sometimes informal, setting. This quasi-judicial function is often referred to as administrative adjudication. The function is not just desirable but also necessary in order to meet the increasing challenges of modern government and administration (Holzer \& Yang, 2005). This is even more so with the surging expansion of democracy and the development of democratic institutions particularly in the emerging countries of Asia and Africa.

With this development came the quest for good governance. Good governance is a relatively emerging concept that seeks to achieve societal balance and justice in its broader sense. Transperancy and accountability in public administration are the principal indicators of good governance (Oladoyin, 2012). Accountability in this respect could be political, managerial or legal depending on the context and circumstances (Mashaw, 2006). The essence is to ensure broader administrative justice. But justice, whether 'administrative' or 'judicial', is an important ideal in governance. Justice and Good governance are therefore, inseparable. Importantly, at the heart of every adjudicatory function is the exercise of discretion. The nature of the latter concept particularly its inherent subjectivity has provoked immense debates in jurisprudence. Can the exercise of administrative discretion be constrained? This question is central to administartive law. While some argue that the exercise of discretionary powers is an antithesis of the rule of law, that is, it is arbitrary and beyond the law, others maintain that it is not (Lewans, 2008). What is clear however, is that the exercise of discretionary powers is an important feature of modern public administration. (Holzer \& Yang, 2005)

This article examines the significance of administrative justice in the attainment of good governnace in Nigeria. It demonstrates the linkage between administrative justice and good governance and argues that an efficient and effective system of administrative justice is crucial to overall good governance. It argues that good governance is an ideal to be obtained not only by reference to the general structure of government in a given polity but also by the quality of justice obtained both in the proper judicial and quasi-judicial bodies. The focus of the article will be on the discretionary powers of administrative agencies and offcials and why they are essential to good governance. It will demonstrate how a narrow conception of administrative justice affected the attainment of good governance in Nigeria over the years. And unless the ideals of justice and fairness are observed and administered within public institutions and administrative justice is seen as essential to proper public administration, good governance will only be a mirage.

In order to achieve these objectives, the article is divided into six sections. The second section clarifies some key concepts that are essential to our subsequent discussions. These concepts include 'justice', 'administrative justice', 'rule of law' and 'good governance'. Section three seeks to situate administrative justice within the general administrative setting. Under this section the nature of administrative discretion will be examined. It equally considers the desirability of administrative justice in modern governments. Section four is the segment that examines administrative justice within the legal and constitutional framework in Nigeria. Section five briefly considers administrative justice as an element of good governance. The section highlights the governance problems in Nigeria and argues that a restrictive approach to administrative justice plus the neglect of first instance decion-makers within the administrative system are some of the obstacles to the attainment of good governance in the country. Section six concludes with some recommendations.

\section{Conceptual Clarifications}

There are certain key concepts that demand brief clarification before embarking upon the task enumerated above. 'Justice', 'administrative justice', 'good governance' and the 'rule of law' are somewhat related concepts having different meanings. It is therefore, imperative to understand these terms within the context of this article.

\subsection{Justice}

Literally, the word 'justice' could mean fairness, impartiality, evenhandedness, uprightness, fair-mindedness, equity, objectivity, neutrality, righteousness, honesty and disinterestedness.(Wehmeier, 2001). In jurisprudence, it has a variety of meanings. It is an abstract concept that has provoked immense debates since the time of the Stoic philosophers who saw it as the ultimate goal of natural law (Freeman, 2001). To these philosophers, justice is 'a constant and perpetual will of giving every one his due', a natural attribute deducible from reason; it is universal, everlasting and unchangeable (Freeman, 2001). The early Christian philosophers such as St. Thomas Acquinas equally saw the concept as a universal moral value but with divine content (Freeman, 2001). John Finnis premised his natural law conception on the needs of the common good and the principle of redistributive justice (Finnis, 1980). He argues that injustice arises where an administrator 'exploits his opportunities by making stipulations intended not for the common good but for his own or his friend's or party's or faction's advantage, or out of malice against some person or group' and that 'the injustice is 'distributive' inasmuch as the official improperly seeks to subject others to his own decisions' (Finnis, 1980). But unlike the Naturalists, the 
Utilitarians saw justice as a virtue necessary for orderly existence of a society, but not founded on reason. For instance, in conceptualising justice on the basis of property rights, Hume maintained that justice 'derives its existence entirely from its necessary use to the intercourse and social state of mankind' (Krause, 2004). To him, the foundation of justice is its necessity and usefulness to both man and society, together with a concern for the public good. An organised society without the rules of justice is bound to 'immediately dissolve' (Krause, 2004).

Hayek insisted that 'government ought to be just in all it does'. He defined justice simply to mean that 'some person or persons ought, or ought not, to have performed some action; and this ought in turn presupposes the recognition of rules which define a set of circumstances wherein a certain kind of conduct is prohibited or required' (Hayek, 1982). John Rawlz was the most popular exponent of the idea of justice in modern jurisprudence. Based on his theoretically constructed 'original position' and 'the veil of ignorance', John Rawls offered two principles of justice: the first principle provides for a system of basic rights and liberties, and the second provides for equality of opportunity (Rawls, 1972). Accordingly, he combined these two principles to produce a general conception of justice:

all social values- liberty and opportunity, income and wealth, and the bases of self-respect- are to be distributed equally unless an unequal distribution of any, or all, of these values is to every one's advantage' (Rawlz, 1972).

Other scholars conceptualised justice from the perspective of property, by 'commodifying' it. For instance, Bierce maintains that 'justice is a commodity which is more or less adulterated... the state sells to the citizen as a reward for his allegiance' (Bierce, 2004). Other scholars championed the idea of justice according to law in order to constrain the use of discretionary powers. Constitutional ideals such as the rule of law, separation of powers, ministerial and administrative responsibility and accountability can be seen as constituents of justice in this wider sense.

This functional approach is largely preferred by the courts in Nigeria. Because they are constantly engaged in the task of dispensing 'formal justice', the courts considered this function as a practical endeavor which involves the balancing of conflicting interests: protecting rights and fixing liabilities. In cases such as Obajimi V. Adediji (2008) and Onwualu V. Mokwe (1999), Nigerian courts upheld this functional approach. Unlike the philosophers, the courts consistently denounced the idea of justice as an abstraction. This approach is not peculiar to the courts, it is a central feature of modern forms of adjudication and dispute settlement.

Therefore, whether abstract, technical or real, justice is a virtue that has a universal appeal. It is at the heart of societal orderly existence and is one of the fundamental functions of the state.

\subsection{Administrative Justice}

Administrative function essentially deals with decision making; it is seen as an extension of the executive function in modern constitutional setting based upon the popular trichotomy of governmental powers, otherwise called separation of powers. From the latter concept administration of justice is the primary responsibility of the Judiciary and therefore, it may seem awkward to talk of 'administrative justice'. However, the latter concept has assumed much significance in the operational framework of modern bureaucratic systems and can be seen within the realm of administrative law. It has been variously defined. For instance, Mashaw defines it from the perspective of societal acceptability.

The "justice" of an administrative system... means simply the qualities of the system that argue for the acceptability of its decisions (Mashaw, 1981).

French defines it as 'the perception of values or attitude about the way in which a decision maker should act' (French, 1999). The Bristol Center for Administrative Justice defines its scope as a system that involves judicial review, tribunals, inquiries, ombudsman and other acceptable complaint procedures (Bristol Center for the Study of Administrative Justice, 1999). It is a complex set of values which includes natural justice, participation, democracy, efficiency, fairness, transperancy, accountability and cost effectiveness. Essentially, it deals with procedures for correcting defective administrative decisions in order to safeguard the ideals of the rule of law (Creyke \& McMillan, 2005).

Galligan conceives it from the perspective of the mechanisms for redress in the general adjudicatory system and he concludes that administrative justice involves the application of 'justice ideas' to the actions of government authorities and other bodies exercising governmental powers (Gilligan, 2009). Adler defines it as 'the justice that inheres in administrative decision making' and conceptualises it from two angles: the 'top-bottom' and the 'bottom-up' conceptions (Adler, 2006a). The former sees administrative justice in terms of the principles enunciated by various redress mechanisms that come into play when people who are unhappy with the outcome 
of an administrative decision or with the process by which that decision was reached, challenge the decision and achieve a determination in their favour (Adler, 2006b). This conception restricts administrative justice to the formal judicial and other related avenues like the courts, tribunals and the Ombudsman system. On the other hand, the 'bottom up' conception broadly sees it in terms of the justice inherent in routine administrative decision making (Adler, 2006b). The focus here is on the level of adherence to the principles of procedural fairness starting with the 'street-level bureaucrat'; it is concerned with the justice inherent in first-instance decisions that characterise most bureacratic setting.

It is submitted that this 'bottom-up' conception of administrative justice is preferable within the context of this article. It is largely ignored in both the academic and administrative circles in Nigeria. The recent UK White Paper on Tribunal Reforms seems to prefer this conception because it sees administrative justice in terms of the normative expectations held by members of the public and is characterised by the following:

a. the decision making system must be designed to minimise errors and uncertainty;

b. the individual must be able to detect when something has gone wrong;

c. the process of putting things right or removing uncertainty must be proportionate - that is, there should be no disproportionate barriers to users in terms of cost, speed or complexity, but misconceived or trivial complaints should be identified and rooted out quickly;

d. those with the power to correct a decision get things right; and

e. changes feed back into the decision making system so that there is less error and uncertainty in the future (UK Department of Constitutional Affairs, 2004).

The bottom-up conception looks beyond the adjudicatory and quasi-adjudicatory functions of the officials. It is a holistic approach that addresses the complexities of modern bureaucracy, tracing administrative inadequacies right from the root. Its focus extends beyond the formal judicial and administrative tribunals. This approach to administrative justice fits into the good governance equation which demands adherence to the rule of law. It means that fairness, objectivity and transperancy must be exhibited by administrative decision makers, from the 'street level' bureaucrat to the top officials in government. It is not limited to the outcome of, or procedures that must be followed in, administrative adjudication.

\subsection{Good Governance}

'Good governance' has become a political and economic mantra at both the national and international planes. Unlike the above two concepts, it has haboured within it much political elements. It emerged to offer explanation for the 'perpetual' poverty, wrechedness and malnutrition that many developing countries have been grappling with for decades. It is a combination of two words: 'good' and 'governance'. The word 'Governance' has been variously defined (Oladoyin, 2012). It is a broader term that literally means general management or administration and control and could be employed in the perspective of different matters, whether in the private or public sectors. In the public sector, governance refers to "the institutional underpinnings of public authority and decision making', and broadly includes the 'institutions, systems, "rules of the game" and other factors that determine how political and economic interactions are structured and how decisions are made and resources allocated' (Grindle, 2010). According to the Commission on Global Governance,

'Governance is the sum of the many ways individuals and institutions, public and private, manage their common affairs. It is a continuing process through which conflicting or diverse interests may be accommodated and co-operative action may be taken. It includes formal institutions and regimes empowered to enforce compliance, as well as informal arrangements that people and institutions either have agreed to or perceive to be in their interest' (Commission on Global Governance, 1995).

Landell-Mills defines governance as 'how people are ruled and how the affairs of a state are administered and regulated. It refers to a nation's system of politics and how this functions in relation to public administration and law. Thus, the concept of governance goes beyond that of "government" to include a political dimension (Nanda, 2006). Others viewed governance as comprising certain key elements such as political accountability, bureuacratic efficiency and fair and transparent legal framework (Oladoyin, 2012).

Similarly, 'good governance' has been variously defined. In Nigeria, it is often confused with the the positive actions of elected officials otherwise called 'democratic dividends' (Edighin \& Etoghile, 2011; Akomolede \& Bosede, 2012). Generally, it implies a virtuous and progressive governance. While describing the concept as a 'fig leaf' invoked by international development agencies to 'invade safely the minefield of domestic politics', Grindle describes it as refering to a 'list of admirable characteristics of how government ought to be carried out', implying the notion that 'good governance is a positive feature of political systems and that bad governance is a problem that countries need to overcome' (Grindle, 2010). Michael Johston defines it as the 'legitimate, 
accountable, and effective ways of obtaining and using public power and resources in the pursuit of widely accepted social goals' (Johnston).

Good governance encompasses different ideals. International donor agencies regard it as a prerequisite for sustainable economic development. For instance, the World Bank considers accountability and transparency, efficiency in how the public sector works, rule of law, and ordered interactions in politics as the key components of good governance (Grindle, 2010: 4-5). And the UNDP considers participation, transparency, accountability, effectiveness, and equity as its most important characteristics. Others include evocative ideas such as justice, fairness, decency and efficiency. In fact, it has become a common hallmark embedded in many countries' development plans.

Good governance sets the normative standards of development. It fosters participation, ensures transparency, demands accountability, promotes efficiency, and upholds the rule of law in economic, political and administrative institutions and processes. (Phillipnes Development Plan, 2011-2016).

However, regardless of the origin and the politics inherent in the concept, it is clear that an effective and efficient system of public administration can only flourish in an atmosphere of openness, transperancy and accountability. Decision making and implementation of government policies may continue without them but such a system will certainly lack credibility and can hardly guarantee fairness. Therefore, the broader conception of administrative justice examined above neatly fits into the good governance spectrum. Importantly, it is generally believed that the basic foundation for good governance is what came to be called the rule of law.

\subsection{The Rule of Law}

The rule of law is very central to the question of legitimacy of administrative justice and it is important to have a thorough understanding of the concept here. It is generally accepted as a component of good governance. Like other concepts, the rule of law has been subjected to a series of ideological, historical and philosophical conjectures. The popular exponent of the concept was A.V. Dicey who theorized and situated the concept within the British constitutional system. To Dicey, the rule of law means the following:

a. the absolute supremacy or predominance of regular law as opposed to the influence of arbitrary power, and excludes the existence of arbitrariness, of prerogative or even of wide discretionary authority on the part of the government.

b. Equality before the law, or the equal subjection of all classes to the law of the land administered by the ordinary law courts.

c. The rules of the constitution are not the source but the consequences of the rights of individuals as defined and enforced by the courts (Dicey, 1959).

From this conception, adminstrative discretion is strongly denounced as antithetical to the spirit of the rule of law. This has generated a lot of criticsms, with one writer calling Dicey's theory as 'utterly confusing and unstable' (Lewans, 2008). Other contemporary scholars offer varied conceptions. For instance, Lane defines rule of law from two perspectives: narrow (Rule of Law I) and broader (rule of law II) perspectives (Lane, 2010). The former deals with principles of legality and independence of the judiciary while the latter deals with constitutionalism and principle of governmental accountability. While rule of law I may exist without rule of law II, the latter cannot exist without the former. Accordingly, a matured constitutional democracy must combine and concretize both. He further maintains that government is in accordance with rule of law 'when it is conducted by means of law, enforced by independent courts...' but 'legality and judicial independence are not enough to secure rule of law in the broad sense of the term. Broad rule of law involves much more than government under the laws, as it calls for inter alia: separation of powers, elections, representation and decentralisation of some sort' (Lane, 2010).

However, the concept of the rule of law is not without its problems. Some have argued that the rule of law is not necessarily a virtous idea; it may be likened to a sharp knife serviceable for good and bad purposes (Raz, 1977). Because every society whether democratic or undemocratic, must have law and be governed under the law, it is safely assumed that all societies have rule of law I in the Lanian sense. In the words of Raz:

The rule of law is a political ideal which a legal system may lack or may possess to a greater or lesser degree...it is just one of the virtues which a legal system may possess and by which it is to be judged. It is not to be confused with democracy, justice, equality, human rights of any kind or respect for persons or for the dignity of man. A non-democratic legal system, based on the denial of human rights, on extensive poverty, on racial segregation, sexual inequalities, and religious persecution, may in principle conform to the requirements of the rule of law better than any of the legal systems of the more enlightened western democracies (Raz, 1977). 
An ambitious exposition of the concept was made by Lord Bingham. He defines it to mean that 'all persons and authorities within the state, whether public or private, should be bound by and entitled to the benefit of the laws publicly and prospectively promulgated and publicly administered in the courts' (Bingham, 2007). He then expounds it further by laying down eight sub-rules as follows:

a. The law must be accessible and so far as possible, intelligible, clear and predictable.

b. That questions on legal rights and liability should ordinarily be resolved by application of the law and not the exercise of discretion.

c. That the laws of the land should apply equally to all, save to the extent that subjective differences justify differentiation.

d. The law must afford adequate protection of fundamental human rights.

e. That means must be provided for resolving without prohibitive cost or inordinate delay bona fide civil disputes which the parties themselves are unable to resolve.

f. That ministers and public officers at all levels must exercise the powers conferred on them reasonably, in good faith for the purpose for which the powers were conferred and without exceeding the limits of such powers.

g. That adjudicative procedures provided by the state should be fair.

$\mathrm{h}$. That the existing principle of the rule of law requires compliance by the state with its obligations in international law, the law which whether deriving from treaty or international custom and practice governs the conduct of nations.

Obviously, most of these sub-rules are subsumed one into another. But the basic principles of legality, equality, fundamental rights and non-abuse of discretionary powers have been recognised under this general conception.

Although there are significant variations, it is clear that all the above theoretical expositions consider the rule of law as a fundamental principle that seeks to restrain and control the exercise of powers through the instrumentality of the law. It is the pillar upon which modern constitutional democracy rests. Govenmental powers, legislative, executive and judicial, are not limitless; nor are the government organs given a blank cheque to operate. The whole purpose is to achieve good governance throught the limitation of powers. This has been the golden principle and in the case of Governor of Lagos V. Ojukwu (1986), the Nigerian Supreme Court has affirmed it in the following tone:

The Nigerian Constitution is founded on the rule of law the primary meaning of which is that every thing must be done according to the law. It means also that government should be conducted within the framework of recognised rules and principles which restrict discretionary power which Coke colourfully spoke of as 'golden and straight metwand of law as opposed to the uncertain and crooked cord of discretion.'

Therefore, the above key concepts are inter-penetrable, one complementing and reinforcing the other. Administrative justice is a specie of justice and the existence of human societies will be meaningless without the administration of justice whether formally or informally. Similarly, rule of law is an ideal that seeks to achieve overall justice through good governance. What needs to be emphasised here is that the concept of rule of law in this context should be understood devoid of any ideological incilination (Galligan, 1986).

\section{The Dilemma of Administrative Discretion}

From the above exposition, a common thread running through all the four concepts is the exercise of discretion. Stricto sensu, in policy formulation or implementation and in any form of decision taking, whether judicial or administrative, exercise of discretion is inexorable. Administrative justice essentially involves the exercise of discretion; but discretion is an uncertain and subjective concept and this partly explains Dicey's aversion to it. It is therefore, imperative to underscore the exercise of discretion by officials and how same can be situated within the province of the rule of law.

\subsection{Nature of Discretion}

Discretion implies individual will, choice or freedom to decide. In legal usage, it connotes personal autonomy in judgement and assessment (Galligan, 1986). According to Galligan (1986: 21-22)

Discretion, ... is most at home in referring to powers delegated within a system of authority to an official or set of officials, where they have some significant scope for settling the reasons and standards according to which that power is to be exercised, and for applying them in the making of specific decisions...central to this is the idea that within a defined area of power the official must reflect upon its purposes, and then settles upon the policies and strategies for achieving them. 
From Galligan's perspective, two principal variables must coincide to produce discretion: the scope for assessment and judgement left open to the decision maker by the terms of his authority, and the surrounding attitudes of officials as to how the issues arising are to be resolved (Galligan, 1986). In this sense, official discretion has the following features.

a. Discretion occurs in the context of standards guiding, constraining and influencing decision making.

b. It is a sub-system of authority within which the official has some degree of freedom and autonomy on decisions regarding policies and standards, strategies for achieving them and applying them to specific cases.

c. In the admistrative context, officials maintain a relationship between general standard and particular cases.

d. The courts determine from a legal point of view whether an official has discretion (Galligan, 1986).

In the context of public administration, administrative discretion has been defined to mean 'the freedom of choice or judgment with which an executive officer or an administrative agency is entrusted in order to ensure the constant and complete effectuation of the legislative policy in any situation which might arise in connection with the enforcement of the statute' (Cooper, 1938: 581). Importantly, it should be added that discretionary powers do not emanate vacuously; they are created, expressly or impliedly, directly or indirectly, and conferred on a person or agency for a general or specific purposes. This process occurs within the legal order which bestows legitimacy on the exercise of such discretion. The question whether the exercise is arbitrary or not is a matter entirely different. The point is, public administration revolves around the exercise of discretionary powers which are simply the products of the legal order. But discretion poses a dilemma: it is necessary but problematic, particularly in the context of the complexities of modern welfare states and the ideal of the rule of law (Holzer \& Yang, 2005).

\subsection{Administrative Agencies and the Exercise of Discretion}

The proliferation of administrative agencies is explainable in terms of the complex structure of modern welfare states. Government's principal function is no longer restricted to the traditional provision of security and protection of life and properties (the minimalist state function); today, government has become a major provider of essential services, venturing into businesses and other fields that were hitherto considered as falling within the private domain. With this expansion in governmental spheres and functions came the necessity for delegation of authority which invariably involves the vesting of discretionary powers on public bodies. Therefore, public authorities and corporations are increasingly being recognized as necessary instruments for public administration. Pound considers this as the hallmark of the structure of modern governments (Pound, 1919). And according to Rosenberry

"Administrative tribunals ... did not come because any one wanted them to come. They came because there seemed to be no other practical way of carrying on the affairs of government and discharging the duties and obligations which an increasingly complex social organization made it necessary for the government to perform" (Rosenberry, 1929)

Therefore, agencies with discretionary powers emerged out of administrative expediences and the near impossibility of any branch of the government to perform all the necessary functions. Also, the desire for effective and efficient administration informs this dispersation and delegation of governmental powers to public agencies. Thus, they are created to augment the increasing expansion of the functions of government. Some of these bodies may perform functions that many will percieve as falling outside the province of government or simply 'non-governmental' functions. Today, it seems difficult to draw a line between strict 'governmental province' and 'non-governmental province'.

This development in turn poses some theoretical and practical challenges in identifying public bodies. For instance, the Halsbury's Laws of England states that 'a public authority may be described as a person or administrative body entrusted with functions to perform for the benefit of the public and not for private profit' but concludes that 'the fact that a person or body exercises functions of a public nature does not conclusively establish that such a person or body is a public authority' (Hailsham, 1973). For our purpose, public bodies or institutions include those established under the constitution or any statutory instrument with the principal aim of discharging or superintending any government activities, functions or businesses. Therefore, any person working for these institutions is a public officer. Once a person is entrusted with an administrative authority to make a decision he becomes a public officer and the manner of exercising the authority conferred could have enormous consequences on general public administration. Decision-makers may consist of the 'street-level bureaucrats' or top government officials. The class of administrators is not material here. In the same vein, the nature of the 
function does not matter; administrators perform pure administrative plus quasi-legislative and quasi-judicial functions.

Implicit in the nature of the powers conferred on, and exercised by, public bodies or their agents is the exercise of discretion. It is the use of discretion that facilitates the implementation of government policies. It is through discretionary powers that most legislative and executive policies are translated into concrete results. Giannatasio quoted Wilson saying that 'the administrator should have and does have a will of his own in the choice of means for accomplishing his work' (Giannatasio, 2005). Another proponent of administrative discretion who staunchly opposes 'judicial meddling' in the field of administration maintains that 'administrative discretion is the life blood upon which the entire administrative process feeds; without its vitalizing contribution the machinery of administration would degenerate into an impotent force with neither purpose nor direction' (Cooper, 1938). Although there is obvious potential for the misuse of administrative discretion (and there are several instances of this) it is undoubtedly of immense significance in modern governance. It is recognised as a means to an end where the ends are the desires of the legislature (Giannatasio, 2005). What is crucial is the question of responsibility and accountability.

Therefore, it is unarguable that public administrators have enormous powers. As stated earlier, the exercise of such discretion may negatively affect the general public. But can it be avoided? Thus, administrative discretion poses a dilemma: it is necessary but problematic. This is where the restraining function of the law comes into play.

\subsection{The Rule of Law and the Control of Administrative Discretion}

The essence of accountability mechanisms in public administration is to control or check excesses and avoid arbitrary use of discretion. There are broadly three accountability mechanisms: political accountability that relates to or belongs to the political realm within the state; managerial accountability that relates to the internal, often pyramidal, administrative structure within a particular public or private institution; and legal accountability or what we may refer to as judicial remedies (the mechanisms founded on the Diceyan notion of the rule of law) that relates to the legal and constitutional structures within the state (Mashaw, 2006). The former two may be situated within the latter but it is not always necessarily so. However, most legal scholars seem to ignore the first two and focus almost exclusively on the third.

Clearly, the law constrains the exercise of administrative discretion particularly through judicial review. As in all human endeavors, regulation of discretionary powers is necessary. This regulation is based upon some elements of the rule of law that is: stability in legal relations, rationality in decision-making, fair procedures and residual category consisting of moral and political principles (Galligan, 1986). The first three are important for our purpose. While stability of legal relations depends on 'official actions being governed by a system of reasonably clear, settled and binding standards' derivable from statutes, case law or subsidiary legislation, rationality in decision-making entails restraining official discretion through principles intrinsic to human rationality (Smith, 1972; Bourne, 1948; William, 1994). In the words of Galligan, 'the most rudimentary requirements of political morality are that in exercising discretionary powers, officials should comply with standards of rationality, purposiveness and morality' (Gilligan, 1986). Thus, no exercise of official discretion should be left to the personal whims and caprices of an individual; a safeguard is required to avert abuse and arbitrary exercise of powers. This has been captured by Gilligan when he states thus;

The general principles that discretionary decisions should be made according to rational reasons means: a) that there be findings of primary facts based on good evidence, and b) that decisions about the facts be made for reasons which serve the purposes of the statute in an intelligible and reasonable manner. Actions which do not meet these threshold requirements are arbitrary, and may be considered a misuse of powers' (Gilligan, 1986: 266).

As noted earlier, fair procedure or due process or procedural justice is central to the idea of the rule of law. It is only applicable in the courts or administrative tribunals but at the level of individual decision-making it is only reasons, purpose and rationality that work.The basic principles of procedural justice are encapsulated in the twin pillars of natural justice: audi alterem partem (hearing both sides) and nemo judex in causa sua (rule against bias). Courts have insisted on these principles and a plethora of administrative decisions were annuled on the basis of their disregard for these principles. For instance, in the popular case of Garba \& Ors V. University of Maiduguri \& Ors (1986) concerning the expulsion of some university students following a riot, the Supreme Court of Nigeria held that the visitor, like any other inferior judge is subject to the control of the common law courts and that even where the matter is one of domestic nature, the courts can inquire whether principles of natural justice were followed. The Court states thus: 
The rules of natural justice must be observed in any adjudication process by any court or tribunal established by law.

However, it is noteworthy that many administrative decisions which involved abuse of discretion do not make it to the courts for review. Importantly, some advocates of total administrative discretion have strenously argued that judicial control of administrative decisions and other legal constraints constitute a clog on the wheels of effective and efficient administration (Cooper, 1938). For instance, while describing the courts as the 'self-appointed supervisors of governmental process', Cooper argues that the judicial control is highly unnecessary. Because of this radical position, his opinion is extensively reproduced thus:

By this process of judicial usurpation the courts rather than the administrators have become the final arbiters as to the content and meaning of national legislative standards. As a practical matter the judiciary is no more fitted to enter the specialized fields of public administration, nor endowed with the technical competence necessary to solve the intricate problems arising in connection with the enforcement of modern legislative policies, than are the legislative bodies which were forced to delegate such functions to specialized tribunals...One of the most serious impediments to the orderly development of a sound system of administrative justice is the assumption that the judiciary is the only agency of government which possesses the capacity to govern (Cooper, 1938: 597, 600).

This arguement should be appreciated within the the context of the then emerging American administrative system. It is doubtful whether the author will express similar opinion today. But in other common law systems the courts have always been the ultimate deciders of the legality of the exercise of administrative decisions, of course they always exercise restraints as stressed in WednesburyCorporation V. Min. Housing and Local Government (1966). The courts play a significant role in the control of discretionary powers particularly through judicial review which is essentially concerned with 'the ideal of the rule of law' (Mullender, 1996). It may be argued that this system favours a restrictive approach to administrative justice. The focus is not on 'street-level bureaucrat' but on the decisions of administrative bodies or tribunals that come before the courts for review. The accountability mechanisms are more or less external.

In the U. K. there appears to be a shift in attitude at least from the government. As noted above, the broader 'bottom-up' conception of administrative justice is becoming the trend so that 'the decision making system must be designed to minimise errors and uncertainty'.It is therefore, imperative that attention be given to the broader notion of adminnistrative justice which should include the other accountability mechanisms. But the focus in Nigeria appears to be in line with the 'up-bottom' approach.

\section{Administrative Justice in Nigeria}

\subsection{Constitutional Framework for Administrative Justice}

The idea of administrative justice in Nigeria is any justice obtainable outside the court system and is seen to represent the outcome of administrative adjudication which has a firm constitutional basis. The necessity for administrative tribunal was felt during the British colonial administration (Iluyomade \& Eka, 1980; Alimi, unpublished). Today, administrative authorities had been statutorily created and conferred with discretionary powers, including quasi-judicial powers. There are five main categories of bodies exercising quasi-judicial functions. They are: specific constitutional and statutory tribunals (eg Code of Conduct Bureau, the various Rent Tribunals, Investment and Securities Tribunals), executive or administrative entities (eg Governors, Ministers, Commissioners), administrative agencies exercersing public functions, the Ombudsman system (the Public Complaint Commission) and disciplinary commitees or bodies established for professional organisations (eg the Legal Practitioners Disciplinary Committee). These authorities perform diverse functions depending on their mandate as may be contained in the instruments establishing them. In particular, they exercise adjudicatory functions and dispense justice but the exercise of this function is subject to legal restraints constitutionally entrenched to ensure procedural justice.

Section 36(2) of the Constitution of the Federal Republic of Nigeria, (CFRN) 1999, provides that:

“... a law shall not be invalidated by reason only that it confers on any government or authority power to determine questions arising in the administration of a law that affects or may affect the civil rights and obligations of any person if such law -

(a) Provides for an opportunity for the person whose rights and obligations may be affected to make representations to the administering authority before that authority makes the decision affecting that person; and 
(b) Contains no provision making the determination of the administering authority final and conclusive."

In Obi V Mbakwe (1985) the court held that a similar provision under the 1979 Constitution aims at ensuring smooth running of the administrative machinery by allowing agents of the executive to determine the rights of the people in accordance with certain laws that might be made from time to time.

Furthermore, the constitution established a number of governmental organs, institutions and agencies to exercise different functions which include pure judicial and quasi-judicial functions. For instance, the constitution provides for the general framework on the exercise of legislative, executive and judicial functions based on the spirit of the separation of powers (CFRN, 1999: sections 4, 5, 6 and parts 5, 6 and 7). Apart from conferring judicial powers on the courts and other tribunals established the the law, the constitution also vests quasi-judicial powers on agencies, ministries and officials under the executive branch. These authorities are required to observe the above constitutional requirement.

\subsection{Administrative Justice and the Common Law in Nigeria}

As in other common law jurisdictions, there are judicial remedies for the abuse of administrative discretion in Nigeria. The courts have powers to control such discretionary use of powers particularly where adjudicatory functions are involved (Okany, 2007). Such decisions may be impeached on the grounds of want or excess of jurisdiction, unreasonableness, denial of natural justice or fair hearing and error of law in the conduct of the proceedings by the tribunal as decided in Shitta-Bey V. Federal Public Service Commission (1980). However, unlike some common law jurisdictions, Nigeria has no specific legislation regarding administrative justice. For instance, the United States has the Administrative Procedure Act, 1946 , and South Africa has the Promotion of Administrative Justice Act, 2000 (PAJA) promulgated principally to ensure administrative justice within the general public administration in the country. The PAJA is an administrative law statute applicable in the whole country. It does not confer administrative discretion but strictly regulate how administrators should exercise such discretion within the confines of the law. It sets out the general rules that govern how administrators must make decisions: procedurally fair and transparent, reasonably and justifiably (Department of Social Development, Women, Children and Person with Disabilities (DSDWCPD), North West Province, 2011). Reasonableness implies that administrators should understand the context of an application for government services before taking a decision (DSDWCPD, 2011). Justification implies that the administrator making a decision must have a legal basis for such decision and procedural fairness means that in making administrative decisions affecting individuals rights, the person likely to be affected must be given adequate notice of the nature and purposes of the proposed decision, a reasonable opportunity to make representation, a clear statement of the administrative action, a notice of a right of review or internal appeal where applicable and adequate notice on the right to request reason for such decision (PAJA, 2000: ss 3-10). Where the decision will affect the public, the administrator must decide whether to hold public inquiry or follow a notice and comment procedure (PAJA, 2000: s4).

Althought legislation such as the South African PAJA, 2000 may be criticised for constraining administrative discretion and could have the effect of having an administrative system built on 'fixed' rules that sacrifice effectiveness and efficiency in public administration for 'stringent legalities'; it is however, a classical model for openness and transparancy in administration. Importantly, the Act could aid the free flow and exchange of information between public administrators and the public. It equally appears to have endorsed the 'bottom-up' approach to administrative justice. The goal is to allow for the participation of the citizens on matters directly affecting them. It does not in any way divest officials of the discretionary powers they possess; it merely broadens the accountability mechanisms to ensure good governance. It is a model that recognises the increasing demand for the rule of law and is a statute of general application in administrative decision making. It recognises the importance of allowing the people to participate in administrative decisions that affect them or to be informed of the processes that eventually led to such decisions. In addition, the South African PAJA explicitly incorporates the ideals of good governance in the field of administration. And there are other good governance regulations that complement the PAJA, 2000 (Madonsela, 2010).

\section{Administrative Justice, Good Governance and the Nigerian Quandary}

Undoubtedly, the accountability mechanisms within a political system can immensely contribute in curbing arbitrariness and unreasonable misuse of discretionary powers by officials. Good governance, devoid of its political elements or its constant invocation by international financial institutions and other donor agencies as precondition for financial aid, has some inherent virtues. As noted earlier, the central indicators of good 
governance include openness, transperancy, accountability and fairness in the running of government (Udumbana, 2011). As it has been observed:

'it is the structure of rules and processes that affect the exercise of power, particularly with regard to openness, participation, accountability, effectiveness and coherence' (Udumbana, 2011).

The imperative of the rule of law and accountability in governance has been recognized by many African countries leading to series of reforms in public administration. For instance, following decades of political maladministration and economic misdirection in the continent, the African Charter on Democracy, Election and Good Governance (ACDEGG) was adopted by the members of the African Union in 2007. The purpose of the Charter extends to the reorganisation and strenghtening of public institutions for effective service delivery and efficiency in governance; it provides for access to and exercise of state power in accordance with the constitution of the state party and the principle of the rule of law; the principles of transparency and fairness in the management of public affairs; and states commited themselves to nurture, support and consolidate good governance (ACDEGG, 2007). This Charter followed the AU Convention on Preventing and Combating Corruption adopted in 2003.

Nigeria has made a lot of policy and legislative efforts and reforms to capture the essence of good governance and translate it into reality (Ocheni \& Nwankwo, 2012). For instance the Economic and Financial Crimes Commission Act, 2004, the Independent Corrupt Practices and Other Related Offences Act, 2000, the Fiscal Responsibility Act, 2007, Code of Conduct, Bureau and Tribunal Act, 1989, and, more recently, the Freedom of Information Act, 2011. All these legislation have as their main purpose the entrenchment of good governance through accountability and the Freedom of Information Act, 2011 in particular seeks to ensure citizens participation and accountability, openness and transperancy in governance and specifically guarantees access to information to the citizens. These Acts complement the general constitutional position on administrative justice and good governance discussed above and other provisions such as section 22 which stresses the role of the media to "highlight the responsibility and accountability of the Government to the people" and section 15 which provides that "Government must eradicate all corrupt practices and abuse of power".

In addition, institutional reforms have been initiated since 1999. Good governance mechanisms aimed at fighting corruption and abuse of powers were institutionalised. Anti-corruption agencies were created and vested with enormous discretionary powers (Oladoyin, 2012; Ocheni \& Nwankwo, 2012; Odinkalu, 2010). These agencies include the Independent Corrupt Practices and Other Related Offences Commission (ICPC), Economic and Financial Crimes Commission (EFCC), Code of Conduct Tribunal, Public Complaint Commission and Nigeria Extractive Industries Transparency Initiative (NEITI) (Oladoyin, 2012; Ocheni \& Nwankwo, 2012).

In spite of these legal and institutional reforms, good governance has eluded Nigeria. Abuse of powers and gross misuse of official discretion have become the key characteristics of public administration in the country. Corruption persists at all levels of government; graft and embezzelment of public resources have perverted the exercise of official discretion; allocation and revocation of rights of occupancy in the name of public purposes have been turned into a private property acquisition scheme; privatization of government businesses and properties to cronies; and a near total collapse of state institutions and apparatus due to poor, abusive, neglect or improper use of discretionary powers by administrators (CLEEN, 2010). And 'lootocracy' by public officials has become a common phenomenon. Odinkalu attributed the problem to the people for vesting the management of public trust and the control of resources and institutions on individuals who have turned embezzelment into 'the raison d'etre of public office' (Odinkalu, 2010). Although it is difficult to agree with this conclusion, the gravity of the situation is immeasurable. Sanitizing a public system turned upside down is undoubtedly a herculean task. Arguably, one fails to fathom the increasing push for unworkable reforms in the face of these realities. It may be argued further that the reforms were not instigated by genuine desire for good governance (Jibrin, 2001).

It is submitted that at the centre of this conundrum is the continuing neglect of other accountability mechanisms and the restrictive 'up-down' approach to administrative justice. Administrative justice goes beyond the traditional administrative adjudication and control by the courts. It starts from the first instance decision-makers who are often neglected. But the first instant decision makers take important administrative decisions that tend to have enormous consequences on public administration. The law as it currently stands takes this category of administrators for granted. And even in the case of top officials, it only intervenes through the common law principles and this occurs only where the court is called upon to review a decision. The newly created institutions have not been able to address the problems. The overwhelming majority of the decisions are therefore left 'unchecked'. It is submitted that the abuse of discretionary powers and the inadequacy of the law to effectively regulate their use through sufficient accountability mechanisms is at the heart of the unending political 
maladministration and economic turmoil that the country has been grappling with. Why not enact a legislation on Administrative Justice so that the scope will be expanded and the 'bottom-up' approach will be incorporated into the general system of public administration in the country? Are discretionary powers so unimportant that they should be left to the 'whims' of the Judge?

The only relevant enactments dealing with general administrative justice are the Ministers' Statutory Powers and Duties (Miscellaneous Provisions) Act, 1958 and the Code of Conduct Bureau and Tribunal Act, 1989. The latter was strengthened by the constitution through the establishment of a Code of Conduct Bureau vested with the responsibility of maintaining 'a high standard of morality in the conduct of government business and to ensure that the actions and behaviour of public officers conform to the highest standards of public morality and accountability' (CFRN, 1999: Third Schedule). Arguably these laws are not only antiquated but also inadequate in dealing with the complexity of modern public administration in the country. They are outdated and contain no substantive provisions on modern administrative justice. Other laws such as the Nigerian Extractive Industries Transparency Initiative Act, 2007 and the Public Procurement Act, 2001 are not meant to deal with the subject directly althought they re-echoed the fundamental need for good governance.

\section{Conclusion}

The fears of arbitrary use of powers have been instrumental in the develoment and formulation of several legal principles in different constitutional systems around the world. It is at the center of administrative law. The latter provides for control methods to preserve individual rights and liberty and avert abuse of powers. It is a mistake to assume that efficiency in public administration and overall governance can not coexist with the legal requirements for regulatory checks. Like in all human endeavors, an efficient system does require some regulations otherwise it will definitely crumble and the state will become anything but a state. But it was also the fears of arbitrary use of discretion that made Dicey to condemn administrative law in Britain. Today, there is no doubt that the exercise of discretionary powers are necessary. Arguably, the Common Law has been instrumental in the slow development of this important aspect of the law in Nigeria. It is from this context that the restrictive approach to administrative justice as 'judicially centred' can be appreciated.

However, this is unhelpful in the light of the increasing complexities of administration in the modern states. It is not enough to simply concieve administrative justice by reference to the decisions of the 'top shots' in the administrative system. Nor should the latter be ignored. It is submitted that a wholistic approach is better. Administrative decisions from the 'root' are too important to be ignored. Administrative justice is too important to be left to the judges to mould and develop. Public administration cannot wait for judicial happenstances; and the society cannot wait either. The problems are too pressing to wait. An administrative justice legislation is urgently needed in Nigeria. It should be the 'Bible' for administrators. Decision-makers must be aware of the legal contraints. This, it is hoped, will lead to attitudinal change and will enhance the capacity of administrators while at the same time protecting the public.

The law of administration is essentially concerned with good governance. It enhances administrative efficiency, reinforces the rule of law and strenghtens good governance. Officials and institutions must be responsive to popular will and democratic norms in the exercise of their powers otherwise the rule of law and good governance will be utterly meaningless. The public should be able to detect errors in administrative decision, it should not be a preserve of the judges only because if public officers are to be held accountable then public scrutiny is essential. It is therefore, important to evolve a broader, conscious administrative justice that can adequately address the problems of public administration in Nigeria. This will undoubtedly help in eliminating or reducing the crisis of confidence in Nigeria's administrative system and encourage good governance.

\section{References}

Adler, M. (2006a). Fairness in Context. Journal of Law and Society, 33(4), 615-638. http://dx.doi.org/10.1111/j.1467-6478.2006.00373.x

Adler, M. (2006b). Tribunal Rerfoms: Proportionate Dispute Resolution and the Pursuit of Administrative Justice. The Modern Law Review, 69(6), 958-985. http://dx.doi.org/10.1111/j.1468-2230.2006.00618.x

Akomolade, I. T., \& Bosede, A. O. (2012). Good Governance, Rule of Law and Constitutionalism in Nigeria. European Journal of Business and Social Sciences, 1(6), 69-85. Retrieved from $\mathrm{http}: / /$ www.ejbss.com/recent.aspx

Alimi, L. O. (n. d.). Administrative Justice within the Framework of the 1999 Constitution.Retrieved from http://www.alimiandco.com/publications/ADMINISTRATIVE\%20ADJUDICATION\%20AND\%20DISCI PLINARY\%20PROCESS\%20WITHIN\%20THE\%20CONSTITUTIONAL\%20FRAMEWORK.pdf 
Bingham, L. (2007). The Rule of Law. The Cambridge Law Journal, (66), 67. http://dx.doi.org/10.1017/S0008197307000037

Bourne, C. B. (1948). Discretionary Powers of Public Authorities: Their Control by the Courts. The University of Toronto Law Journal, 7(2). http://dx.doi.org/10.2307/823831

Bristol Center for the Study of Administrative Justice. (1999). Standing Conference on Resolution of Citizen's Grievances. In J. McMillan, \& R. Creyke (Eds.), Administrative Justice: the Core and the Fringe (AIAL, p. 58).

CLEEN Foundationn. (2010). Corruption and Governance Challenges in Nigeria. Conference Proceedings. Lagos: CLEEN Foundation.

Cooper, R. M. (1938). Administrative Justice and the Role of Discretion. The Yale Law Journal, 47(4), 577-602. http://dx.doi.org/10.2307/791857

Creyke, R, \& McMillan, J. (2005). Control of Government Action: Text, Cases and Commentary. London: Butterworths.

de Smith, S. A. (1972). Judicial Review and Administrative Discretionary Powers. The Modern Law Review, 35(4), 415-418.

Dicey, A. V. (1959). Introduction to the Law of the Constitution. London: Macmillan.

Edigin, L. U., \& Otoghile, A. (2011). Good Governance and Democratic Dividends in Nigeria: The Nexus. Pakistan Journal of Social Sciences, 8(1), 23-26. http://dx.doi.org/10.3923/pjssci.2011.23.26

Finnis, J. M. (1980).Natural Law and Natural Rights. London: Clarendon Press.

Freeman, M. D. A. (2001).Llyod's Introduction to Jurisprudence (7th ed.). London: Sweet and Maxwell.

Galligan, D. J. (1986). Discretionary Powers: A Legal Study of Official Discretion. Oxford: Clarendon Press.

Giannatasio, N. A. (2005). The Discretionary Function Exemption: Legislation and Case Law. Public Administration Quarterly, 29(1/2), 201-229.

Grindle, M. (2010). Good Governance: the Inflation of an Idea. Harvard Kennedy School Research Working Paper Series (RWP10-023). Retrieved from http://www.hks.harvard.edu/rwp.pdf

Hailsham, L. (1973). Halsbury's Laws of England (Vol. 1, 4th ed.). London: Butterworths.

Hayek, F. A. (1982). Law, Legislation and Liberty. London: Routledge and Kegan Paul.

Holzer, M., \& Yang, K. (2005). Administrative Discretion in a Turbulent Time: An Introduction. Public Administration Quarterly, 29(1/2), 128-139.

Ibrahim L., \& Femi, O. (Eds.). (2001). Fighting Corruption and Organised Crime in Nigeria: Challenges for the New Millenium. Ibadan: Spectrum Books Ltd.

Iluyomade, B. O., \& Eka, B. U. (1980). Cases and Materials on Administrative Law in Nigerian. Ife, Nigeria: Obafemi Awolowo University Press.

Jackson, P., \& Leopold, P. (2001). Hood Phillips and Jackson Constitutional and Administrative Law. (8th ed). London: Sweet and Maxwell.

Johnston, M. (2006). Good Governance: Rule of Law, Transparency and Accountability. Retrieved from http://unpan1.un.org/intradoc/groups/public/documents/un/unpan010193.pdf

Krause, S. R. (2004, October). Hume and the (False) Luster of Justice. Political Theory, 32(5), 628-655. http://dx.doi.org/10.1177/0090591704264465

Lane, J. E. (2010). Good Governance: the Two Meanings of "Rule of Law". International Journal of Politics and Good Governance, 1(1.1), Quarter I, 2-5.

Lewans, M. (2008). Rethinking the Diceyan Dialectic. University of Toronto Law Journal, 58(1), 75-104. http://dx.doi.org/10.3138/utlj.58.1.75

Madonzela, T. (2010). Corruption and Governance Challenges: The South African Perspective, in CLEEN Foundationn, (2010) Corruption and Governance Challenges in Nigeria,Conference Proceedings. Lagos: CLEEN Foundation.

Mashaw J. L. (1981, April). Conflict and Compromise Among Models of Administrative Justice. Duke Law Journal, 1981(2), 181-212. http://dx.doi.org/10.2307/1372154 
Mashaw, J. L. (2006, April). Recovering American Administrative Law: Federalist Foundations, 1787-1801. The Yale Law Journal, 115(6), 1256-1344. http://dx.doi.org/10.2307/20455655

Mullender, R. (1996). Judicial Review and the Rule of Law. 112 L.Q.R.182.

Nanda P. V. (2006). The "Good Governance" Concept Revisited. Annals of the American Academy of Political and Social Science, 603, 269-283. http://dx.doi.org/10.1177/0002716205282847

Ocheni S., \& Nwankwo, B. C. (2012). The Effectiveness of Anti-Corruption Agencies in Enhancing Good Governance and Sustainable Developmental Growth in Africa: The Nigeria Paradox Under Obasanjo Administration, 2003-2007. Canadian Social Science, $8(3), \quad$ 16-21. http://dx.doi.org/10.3968/j.css.1923669720120803.3120.

Odinkalu, A. C. (2010). Corruption and Governance in Africa: How Do We Break the Circle in Nigeria?. In CLEEN Foundationn, Corruption and Governance Challenges in Nigeria, Conference Proceedings. Lagos: CLEEN Foundation.

Okany, M. C. (2007). Nigerian Administrative Law. Onitsha, Nigeria: Africana First Publishers Ltd.

Oladoyin, A. M. (2012). Anti-Corruption Agencies and the Search for Good Governance at the Grass Root in Nigeria. Global Journal of Human Social Science (A), xii(xi), Version 1.

Oyewo, O. (2007). Constitutions, Good Governance and Corruption: Challenges and Prospects for Nigeria. Retrieved from http://www.enelsyn.gr/papers/w16/Paper\%20by\%20Prof\%20Oyelowo\%20Oyewo.pdf

Rawls, J. (1972). A Theory of Justice. Oxford: Oxford University Press.

Raz, J. (1977). The Rule of Law and its Virtue. The Law Quarterly Review, 93, 195.

Rosenberry. (1929). Administrative Law and the Constitution. 23 AM. POL. Sci. REV. 32.

Sally, W. (Ed.). (2001). Oxford Advanced Learner's Dictionary (6th ed.). Oxford: Oxford University Press.

\section{Treaties and Statutory Instruments}

African Charter on Democracy, Election and Good Governance Adopted on 30th Ianuary, 2007 by the 8th Ordinary Session of the African Union Assembly at Adis Ababa.

Constitution of the Federal Republic of Nigeria, 1999.

Code of Conduct Bureau and Tribunal Act, 1989, CAP.C15 Laws of the Federation of Nigeria, 2004.

Economic and Financial Crimes Commission Act, CAP.C15, Laws of the Federation of Nigeria, 2004.

Fiscal Responsibility Act, 2007.

Independent Corrupt Practices and Other Related Offences Act, 2000, CAPC31,Laws of the Federation of Nigeria, 2004.

Promotion of Administrative Justice Act, 2000 (PAJA), South Africa.

South African Constitution, 1996.

Administrative Procedure Act, 1946, USA.

\section{Decided Cases}

Abiola V. FRN (1995) 7 NWLR (Pt.405)1.

Associated Provincial Picture Houses V. Wednesbury Corporation (1948) 1 K.B.223.

Garba V University of Maiduguri (1986) 1 SC 12

Governor of Lagos V. Ojukwu (1986) 1 NWLR 621

Obi V Mbakwe (1985) 6 NCLR 783 at 793

Onwualu V. Mokwe (1999) 1 NWLR (Pt.585)152

R.V. Cambridge Health Authority, ex p. B. (1995) 1 W.L.R. 898

Shitta-Bey V. Federal Public Service Commission (1980) S.C. 40

Wednesbury Corporation V. Ministry of Housing and Local Government No.2 (1966) 2 Q.B.275 


\section{Copyrights}

Copyright for this article is retained by the author(s), with first publication rights granted to the journal.

This is an open-access article distributed under the terms and conditions of the Creative Commons Attribution license (http://creativecommons.org/licenses/by/3.0/). 